HStud 25 (2011)2, 215-225

DOI: 10.1556/HStud.25.2011.2.4

\title{
CENTRAL AND EASTERN EUROPE IN THE WORLD ECONOMY: PAST AND PROSPECTS
}

\author{
IVAN T. BEREND \\ University of California \\ Los Angeles, CA, USA
}

\begin{abstract}
This article offers an overview of some of the most important economic trends in Central and Eastern Europe from a comparative perspective. It also ventures tentative predictions concerning the economic future of the region.
\end{abstract}

Keywords: Central Europe, Eastern Europe, economy, economic history, comparative economics

\section{What is Central and Eastern Europe?}

Central and Eastern Europe has various historical-geographical definitions. In my interpretation it is a historical unit east from the 19th meridian, or along the River Elbe, that divides Europe in half. During the second half of the 20th century it was the "Soviet Bloc"; and currently, it is the region of the "transforming" countries. The concept of two Europes - West and East - is as old as modern historiography. Leopold von Ranke already in the early 19th century differentiated between the peoples and histories of the two halves of the continent (Ranke, [1824] 1909). Jenö Szücs noted that the River Elbe separated these two parts of Europe in 815, when that was the eastern border of the Christian-feudal Carolingian Empire, markedly different from the pagan, nomadic east. Accidentally, in 1945, the American and Russian armies met at the River Elbe and, soon created two opposing world systems on either side of it (Szúcs, 1983).

Indeed, Central and Eastern Europe shares important characteristics. Compared to the West, history 'began' here half a millennium later, only in the 9th-10th centuries when the first permanent states were established, Christianity, feudal institutions, noble privileges, serfdom, private ownership, and land cultivation were introduced. Even in the 13th to the 15th centuries, this entire region remained a kind of 'frontier' (N. Berend, 2001), open to Asian invasions and Mongol and Ottoman occupations. Between the 15th and 19th centuries, the region could not follow the rise of the modern, merchant, industrializing Western capital- 
ism. Instead it became the raw material and food-supplying periphery, re-feudalized in the capitalist world system (Wallerstein, 1974).

The social fabric, in contrast to the Western bourgeois society with its "disappearing" peasantry, majority working class, and modern entrepreneurial elite, preserved the traditional elements, old social layers and structures characterized a "Dual Society" while modern, mostly non-indigenous, German and Jewish middle class, and a small working class began emerging. In the Balkans, an almost entirely peasant, "incomplete", or elite-less society existed where bureaucratic-military elite filled the gap.

Oscar Jászi (1964) called this area the "unfinished part of Europe" where nation building did not follow the Western pattern and actually was finishing in the present. At the beginning of the 19th century, three multi national empires dominated the area, in the early 20th century eight states existed in the region, while in the early 21 st century, already twenty-eight.

\section{The Development Level of the Region at the End of the Long-19th Century}

Until the early-20th century, this region remained the agricultural half of Europe where the infrastructure and income level - GDP per capita - hardly reached more than one-third to one-half of the West European core's. If we add the level of human capital, the health and educational standard of the region compared to the Western core, we get the full picture of Central and eastern European backwardness: life expectancy at birth before World War I was between 35-40 years, 10-15 years less than in the West. Educational level is well characterized that illiteracy, virtually disappeared in the West still represented $1 / 3$ to $2 / 3$ of the population.

The generalization of the Central and Eastern Europe characteristics, however, requires some further qualification. As Tables 1-3 reflect, all the comparisons show economic and social backwardness. However, in a broader European relationship the picture is much less dark. Before World War I, we can differentiate among four European regions regarding the level of economic development. 1) The advanced, industrialized, modernized Western Europe, including the western provinces of Austria-Hungary and North Italy. 2) At the other end of the spectrum the region of failed modernization in the Balkans and the borderlands of Austria-Hungary. 3) Another highly pre-industrial region, but with advanced industrial pockets in Russia, Spain, Portugal and South Italy. 4) At last, our region under investigation was a semi-successful modernizer. Central Europe, i.e. Poland, Hungary, together with the Baltic area, Finland and Ireland, emerged on the road of modernization and developed an agricultural-industrial structure. The area of investigation thus occupied a medium level of development. Interesting to note: the semi-successful modernizer countries were not independent nation states, but 
Table 1. Development level of the railroads in 1911

(Berend and Ránki, 1982, 100)

\begin{tabular}{lcccc}
\hline Region & $\begin{array}{c}\text { Land area } / 1 \mathrm{~km} \\
\text { railroad } \\
\text { (in sq km) }\end{array}$ & $\begin{array}{c}\text { Length of } \\
\text { railroad/100,000 } \\
\text { inhabitants }\end{array}$ & $\begin{array}{c}\text { Weight of transported } \\
\text { goods/100,000 } \\
\text { inhabitants } \\
\text { (in 100,000 tons) }\end{array}$ & $\begin{array}{c}\text { No. of railway } \\
\text { journeys/ } \\
\text { inhabitants }\end{array}$ \\
\hline European Core & 10.14 & 90.2 & 8.18 & 21.9 \\
C\&E E & 20.49 & 50.4 & 1.59 & 1.7 \\
\hline
\end{tabular}

Table 2. Employment of the active population by sectors in 1913

(Based on Broadberry and O’Rourke, 2010, 61, 70; Berend and Ránki, 1982, 159)

\begin{tabular}{lcccc}
\hline Region & Agriculture & Industry & Services & Industrialization/capita* \\
\hline North West Europe & 20.9 & 39.5 & 39.6 & 55 \\
C\&E E & 69.8 & 18.3 & 11.9 & 18 \\
\hline
\end{tabular}

* Great Britain in $1900=100$

Table 3. GDP per capita in 1913

(Maddison, 1995, 228)

\begin{tabular}{lcc}
\hline Region & GDP/capita (in 1990 dollar) & $\%$ \\
\hline Western Europe & 3,704 & 100 \\
Central and Eastern Europe & 1,690 & 45.6 \\
\hline
\end{tabular}

parts of the multinational British, Russian, or Habsburg empires. All of Finland, the Baltic region, Ireland, Poland and Hungary profited from the huge imperial markets, including their financial markets (Berend, 2011, forthcoming). As recent research documented, independent developing countries received much less capital, and had to pay much higher interest rates for it (Fergusson and Schularik, 2006, 297; Flandreau and Flores, 2009, 679). ${ }^{1}$

\section{The Development Level of the Region at the End of the Short-20th Century}

In the "short-20th century" between 1913 and 1989, Central and Eastern Europe made desperate attempts to industrialize and modernize. That was the age of bitter revolts on the European peripheries. Learning the lessons from the successful German war economic regime during the Great War, all of the peripheries introduced newly invented alternative, state dictated economic regimes to replace liberal, free trade, export-led policies. Fascist-authoritarian economic dirigisme became dominant in Mediterranean Europe, including Italy, Spain, Portugal, and Greece; while the world first non-market, centrally planned economy wanted elevating Russia from lagging behind the West by 50-100 years to reach its eco- 
nomic level in 10 years as Stalin declared in 1931. The countries of the region that regained independence after World War I turned to economic nationalism, high protective tariffs and strong state interventionism in their effort to catch-up with the West that failed before the war when they followed free trade and export-led industrialization policy.

The newly independent but radically "redesigned" (Poland, Hungary, and Romania) and partly newly created countries (Czechoslovakia and Yugoslavia) needed two decades between the wars to somewhat adjust to the new situation among their new borders. Moreover, those decades were pretty depressed years with long period of economic chaos in the immediate postwar years with high inflation, than a devastating Great Depression that hit hard the agricultural and indebted countries. Economic growth characterized the short years of the second half of the 1920s and then the later 1930s, thus economic growth slowed down significantly. None of the countries of the region succeeded in industrialization. They preserved, in the best case, their agricultural-industrial structure.

Table 4. GDP per capita, 1913-50

(Maddison, 1995, 228)

\begin{tabular}{cccc}
\hline Year & $\begin{array}{c}\text { Western Europe } \\
(23 \text { countries })\end{array}$ & $\begin{array}{c}\text { Central and Eastern } \\
\text { Europe }(9 \text { countries })\end{array}$ & $\begin{array}{c}\text { C-E-E in \% } \\
\text { of W-E }\end{array}$ \\
\hline 1913 & 3,704 & 1,690 & 45.6 \\
1950 & 5,126 & 2,631 & 51.3 \\
\hline
\end{tabular}

Central and Eastern Europe definitely became more self-sufficient, especially in industrial consumer good production such as textile, leather, paper, etc. Their progress in developing certain industrial sectors explains the slow advance and reaching of somewhat more than half of the Western economic level.

This progress nevertheless was rather ambivalent since the advance happened in internationally obsolete and already declining branches. The region, in other words, went against the main stream of modern structural changes. Hungary, for example, increased its textile and paper output by four-times in the interwar decades, and instead of importing 70 percent of its consumed textile goods (in 1913), entirely covered domestic consumption by the 1930s. Bulgaria became 80 percent self-sufficient in covering its industrial consumer good consumption. Modern engineering, car, and chemical industries, on the other hand - except a few modern factories in some of the countries - had remained behind, or non-existent. Most of the modern sectors were financed by foreign investments before World War I, and capital inflow to the region except a few years in the second half of the 1920s, stopped. Modern technology import also dramatically declined. In spite of the striking grain crisis in the period, agricultural output was not diversi- 
fied and one-sided grain cultivation remained virtually unchanged. Traditional agricultural and raw material export decreased only from 60 percent to 59 percent in Hungary, remained unchanged, 76 percent in Poland, while in Yugoslavia and Romania, their share were 96 percent and 83 percent, respectively, before World War II.

Rigid social hierarchy and class society, obsolete social characteristics, exclusion of the peasantry from the society blocking social mobility, and preserving the noble-gentry value system remained almost untouched. Education, in spite of spreading literacy, remained a stage behind the West because secondary education was elitist and extremely limited, in the best case between 5 percent and 10 percent of the generation, while higher education enrolled only 1 percent -1.5 percent of the age group.

The second half of the short 20th century was the period of communist economic experiment throughout Central and Eastern Europe. The policy of forced capital accumulation and industrialization, the brutal method that uprooted the peasantry from their land, and the authoritarian political regimes definitely had certain success in transforming the region. Most notably, the often cast like social hierarchy was eliminated and - in the first few decades - an unprecedented social mobility and a real educational revolution modernized the society. Secondary education became virtually general, and higher education enrolled about 15 percent of the given age group. However, the content and structure of education, its' over specialization, practical, and vocational orientation did not follow modern educational trends.

Increased capital accumulation from the interwar average 6 percent of the GDP jumped to 20-25 percent of it and with massive investments, the countries of the region, after the slow interwar decades, generated the highest economic growth of 3.9 percent per annum, i.e., the fastest growth to date, and became industrialized during the 1960-70s. The isolated Soviet Bloc, however, created severe obstacles for real modernization. The area, as all of the peripheral regions, has never pioneered technological inventions and needed technology import. The Cold War era, however, made technology transfer impossible because the Western ban of technology and know how export, the strict CoCom list did not allow following the new communication revolution that revolutionized the entire communication, services, and industry. With tremendous sacrifices of the population, Central and Eastern Europe, thus, at the end, was unable to adjust to the structural requirement of the age and reproduced backwardness in a different form. The computer revolution stopped at the borders of the region and the new high- and medium-high tech industries did not develop. Meanwhile, postwar Western Europe also experienced its unique prosperity and extremely rapid economic growth. This became characteristic both in the par excellence West and also for the former Mediterra- 
nean peripheries that had the highest growth rate in the continent and started joining the core.

From the mid-1970s, after the Oil Crisis and the emerging new structural crisis, rapid growth stopped in the region. Moreover, a serious indebtedness crisis emerged, because all of the communist countries tried to assure political stability by overbridging the crisis ridden years with foreign credits to keep full employment and living standard intact. The regions indebtedness increased from $\$ 6$ billion to $\$ 100$ billion in a few years, and about 80 percent of the credits were consumed. Repayment consequently became more and more difficult, and some of the countries became insolvent and asked for rescheduling repayments. Rapid growth was replaced by near stagnation, and during the last years of the 1980s, even decline in some of the countries. Altogether, in spite of the undoubtedly important social and educational modernization, the most lasting achievement of the communist experiment, in spite of successful and rapid industrialization, Central and Eastern Europe remained on the periphery of the continent, unable to catch-up with the West, moreover, even sliding further behind (Berend, 2009).

Table 5. Comparative economic growth, 1950-92* (Maddison, 2001, 186; 1995, 201)

\begin{tabular}{lcccccccc}
\hline Region & \multicolumn{2}{c}{ GDP/capita, } & & \multicolumn{3}{c}{ GDP/capita, } & Growth rate, & Growth rate, \\
\cline { 2 - 3 } & 1950 & $\%$ & & 1992 & $\%$ & & $1950-73$ & $1973-92$ \\
\hline Western Europe & 5,126 & 100 & & 17,387 & 100 & 4.8 & 2.0 \\
Central and East Europe & 2,631 & 51.3 & & 4,665 & 37.3 & 3.79 & -0.7 \\
\hline
\end{tabular}

* Because a great part, although not the entire decline after the collapse of communism was a consequence of the previous "misdevelopment", the closing year in this table is not 1989, but 1992.

\section{Prospects: Central and Eastern Europe's Development in the 21st Century}

Post-communist transformation, at the immediate post-1989 period, as Joseph Stiglitz called it, was "mismanaged" (Stiglitz, 2003) and a neo-liberal, "one-size-fit-all" strait jacket was virtually forced to the entire region. The West applauded the ill-advised "shock therapy" and the sudden opening, market and price liberalization of the countries and a fast privatization attempt led to a tragic decline of 20-25 percent of the GDP, about 50 percent decrease of agricultural and 20 percent to 30 percent decline of industrial output. 
The region, however, immediately received assistance from the West. The European Union soon accepted the application of several of the former communist countries, including former Soviet republics, and eight Central and Eastern European countries became member of the European Union in 2004, and then two more in 2007. All of these countries became members of the NATO, and the new political arrangement stabilized the political and international situation of the region. Moreover, from the years of European Union candidacy, financial assistance started inflow to the region that reached one-third of the budget of the European Union. This went hand in hand with a huge inflow of foreign direct investments and credits. The entire banking sector was newly created by more than 80 percent foreign participation, and the leading multinational companies established subsidiaries in the modern high- and medium-high tech sectors, initiated research and development and brought the best modern technology into the region. Between 1989 and 2004, \$161,255 million capital flowed in to Central Europe and the Baltic area, and another $\$ 41,903$ million to the Balkans (EBRD, 2005, 19). Labor productivity and economic growth gained a new impulse and went hand in hand with a radical structural modernization.

Table 6. Structural changes after the regime change, 2005

(Economist, 2006)

\begin{tabular}{|c|c|c|c|c|c|c|}
\hline \multirow[b]{2}{*}{ Region } & \multicolumn{2}{|c|}{ Agriculture } & \multicolumn{2}{|c|}{ Industry } & \multicolumn{2}{|c|}{ Services } \\
\hline & $\begin{array}{l}\% \text { of } \\
\text { GDP }\end{array}$ & $\begin{array}{c}\% \text { of } \\
\text { employment }\end{array}$ & $\begin{array}{l}\% \text { of } \\
\text { GDP }\end{array}$ & $\begin{array}{c}\% \text { of } \\
\text { employment }\end{array}$ & $\begin{array}{l}\% \text { of } \\
\text { GDP }\end{array}$ & $\begin{array}{c}\% \text { of } \\
\text { employment }\end{array}$ \\
\hline West Europe* & 2.0 & 4.4 & 27.0 & 31.2 & 70.0 & 66 \\
\hline Eastern** Europe & 4.9 & 12.7 & 32.8 & 36.7 & 62.3 & 56 \\
\hline East in $\%$ of West & 2.45 & 2.89 & 1.28 & 1.18 & 0.91 & 0.85 \\
\hline
\end{tabular}

* European Union 15 or Eurozone; ** 9 countries: all of the Central European and Baltic countries plus Romania.

Although the role of agriculture and industry in the GDP and employment are still 2.5-3 times and 1.2 times, retrospectively, bigger than in the West, while the service sector is still somewhat smaller than in the West, in spite of these legacy of the past, the sectoral structure of the economy, first time in the history of the region, became quite similar to the Western structure.

Labor productivity the best mirror of technological and managerial development, as well as work ethic, was \$5-7 per hour in Central and Eastern Europe, thus only one-quarter to one-third of the Western level of \$25-28 in 1990. During the transformation years when the European Union reached an average 1.4 percent annual increase of productivity, the transforming countries had 3-4 percent increase, i.e., their productivity level in the various countries of the region increased 
at least by 50 percent, or doubled and even tripled, thus reached about half of the Western productivity level.

After the severe decline in the first transformation years, the region's economy gradually recuperated: from 1993 economic growth returned and between 1993 and 2003, reached 4-5 percent per year in Central Europe and the Baltic area. While the region's per capita GDP reached only 37 percent of the West European level in 1992, by 2005, reached its 46 percent (virtually the same level as in 1973, and exactly the same as in 1913). Central Europe reached the 1989 per capita GDP level by 2000 , and surpassed that by 50 percent by 2010 . The entire Soviet Bloc, however, recovered the 1989 level only by 2010. Meanwhile income differences significantly increased:

Table 7. Income inequality (Gini index*)

(Based on Broadberry and O'Rourke, 2010, 398)

\begin{tabular}{lll}
\hline Region & 1985 & 2000 \\
\hline Germany, France, Sweden and the Netherlands & 25.5 & 29.3 \\
Central and Eastern Europe (8 countries) & 22.1 & 31.2 \\
Russia & 23.8 & 45.6 \\
Britain and Italy & 29.5 & 36.0 \\
\hline
\end{tabular}

* The Gini Index $=0$, if everybody has the same income, 100 if one person gets all of the income of a country.

Looking back to the last two centuries, the picture is rather depressing. In relative terms, comparing to Western Europe, Central and Eastern Europe is far behind its 1820 relative level, and could not reach the 1870 relative level either. Varying calculations reflect less than half or even hardly more than one-third of the Western level in Central and Eastern European by 2005:

Table 8. GDP/capita in Central and Eastern Europe ( 9 countries) in \% of West Europe (23 countries)

(Teodorovich et al., 2005, 326; Maddison, 1995, 228; Broadberry and O'Rourke, 2010, 299, 302)

\begin{tabular}{lc}
\hline \multicolumn{2}{c}{ East in \% of West Europe } \\
\hline Teodorovich and Maddison & Broadberry and O'Rourke \\
\hline 59 & 57 \\
51 & 48 \\
46 & 49 \\
51 & 46 \\
47 & 44 \\
40 & - \\
39 & - \\
46 & 35 \\
\hline
\end{tabular}




\section{Forecasts for the Coming Decades}

A promising one-, one-and-half decades of gradual catching-up period with the West, faster growth rates and productivity increase, stopped in 2007-09. The financial crisis hit the world, Europe, including the transforming countries. Economic growth, however is returning to the world. What would the future bring to Central and Eastern Europe? According to one of the most authentic quantifiers, Angus Maddison, Central Europe may reach an annual 1.79 percent annual growth between 2003 and 2030, while Western Europe will have 1.75 percent. If this is the case, the existing gap would hardly change and Central and Eastern Europe remains on the European periphery. Europe as a whole, and Central and Eastern Europe is losing its share from the world economy because of the much faster rising new Asian and overseas economies. Maddison's calculation shows a continuous sharp European decline:

Table 9. Shares from the world's GDP (Maddison, 2007, 340)

\begin{tabular}{lrrrrrr}
\hline Regions & 1820 & 1870 & 1950 & 1973 & 2003 & 2030 \\
\hline West Europe & 23.0 & 33.1 & 26.2 & 25.6 & 19.2 & 13.0 \\
East Europe & 3.6 & 4.5 & 3.5 & 3.4 & 1.9 & 1.3 \\
\hline
\end{tabular}

A more realistic forecast by Nicholas Crafts, however, calculates 4 percent long-term economic growth per year in Central and Eastern Europe, while - according to the same calculations - the West also continues with more or less the same growth rate as before 2008, i.e., about 2 percent. In this case the catching-up process may continue but requires at least the greatest part of the 21 st century (Crafts, 2006, 40).

In full agreement with Grzegorz Kołodko, one has to add: there is not one single future for Central and Eastern Europe. Kołodko differentiates among four possible paths: 1) vanguard group of a very few countries: 7.5 percent annual growth; 2) Bulk of Central Europe 3-4 percent; 3) a group of 2-3 percent annual growth; and at last, 4) some Balkan countries with less than 2 percent growth (Kołodko, 2001). In this case, a small part of the region will catch-up with the West relatively fast, while some parts of the region will be unable to get closer to the West, moreover, some countries may decline further back.

The 2008-10 economic crisis calls the attention for cautious forecasts. The depressing experience and fragility of Greece, Ireland, Portugal, and Spain, countries that started emerging from the peripheries from the 1970s-80s and exhibited modern history's most impressing catching-up success, all of a sudden sharply de- 
clined because the dualistic character of the transforming countries unveiled the weakness of the genuinely domestic sectors. A third of a century is not a long period in historical measures.

Historical forecasts, however, are always the extrapolation of existing trends, while history is a complex process of continuity and change. Historians, in the end, are not futurologists.

\section{References}

Berend, Ivan T. (2005) 'What is Central and Eastern Europe?' European Journal of Social Theory, Vol. 8, No. 4, 401-16.

Berend, Ivan T. (2011) An Economic History of 19th Century Europe: A Regional Approach (Cambridge: Cambridge University Press) (forthcoming).

Berend, Ivan T. (2009) From the Soviet Bloc to the European Union. The Economic and Social Transformation of Central and Eastern Europe Since 1973 (Cambridge: Cambridge University Press).

Berend, Ivan and György Ránki (1982) The European Periphery and Industrialization 1780-1914 (Cambridge: Cambridge University Press).

Berend, Nora (2001) At the Gate of Christendom (Cambridge: Cambridge University Press).

Broadberry, Stephen and Kevin H. O'Rourke (2010) The Cambridge Economic History of Modern Europe Vol. 1: 1700-1870, Vol. 2: 1870 to the Present (Cambridge: Cambridge University Press).

Crafts, Nicholas (2006) 'The World Economy in the 1990s' in Paul W. Rhode and Gianni Toniolo (eds), The Global Economy in the 1990s: A Long-run Perspective (Cambridge: Cambridge University Press).

EBRD (2005) Transition Report Update 2005 (London: European Bank for Reconstruction and Development).

[The] Economist. World in Figures 2006 (2006) (London: Profile Books).

Fergusson, Niall and Moritz Schularik (2006) 'The Empire Effect: The Determinant of Country Risk in the First Age of Globalization, 1880-1913' The Journal of Economic History, Vol. 66, No. 2.

Flandreau, Marc and Juan H. Flores (2009) 'Bonds and Brands: Foundation of Sovereign Debts Markets, 1820-39' The Journal of Economic History, Vol. 69. No. 3.

Jászi, Oscar (1964) The Dissolution of the Habsburg Monarchy (Chicago: University of Chicago Press).

Kołodko, Grzegorz (2001) Globalizacja a perspektywy rozwoju krajow posocjalistycznych torun (Warsaw: Wydawnictwo Dom Organizatora).

Maddison, Angus (1995) Monitoring the World Economy, 1820-1992 (Paris: OECD).

Maddison, Angus (2001) The World Economy. A Millenial Perspective (Paris: OECD).

Maddison, Angus (2007) Contours of the World Economy, 1-2030 AD, Essays in Macro-economic History (Oxford: Oxford University Press).

Ranke, Leopold ([1824] 1909) History of the Latin and Teutonic Nations (1494 to 1514) (London: George Bell).

Stiglitz, Joseph (2003) Globalization and Its Discontent (New York: W.W. Norton \& Co.).

Szűcs, Jenő (1983) Vázlat Európa három történeti régiójáról (Budapest: Magvető Kiadó). 
Teodorovich, Ivan, Željko Lovrinčević, Davor Mikulić, Mustafa Nušinović and Stjepan Zdunić (2005) The Croatian Economic Development. Transition Towards the Market Economy (Zagreb: Institute of Economics).

Wallerstein, Immanuel (1974) The Modern World System: Capitalist Agriculture and the Origins of the European World-Economy in the Sixteenth Century (New York: Academic Press).

\section{Note}

1 Independent developing countries had 180 basis point higher interest rates than British colonies in India and Africa. Even backward, autocratic empires such as the Russian and Ottoman were preferred borrowers "precisely because they were strong... [and] credible underwriters came to monopolize the market for good sovereign debt". 